\title{
Wild Vegetables Used by Local Community of Makawanpur District and Their Contribution to Food Security and Income Generation
}

\author{
Nirmala Joshi ${ }^{1}$ and Mohan Siwakoti ${ }^{2}$ \\ ${ }^{1}$ Department of Plant Resources \\ Thapathali, Kathmandu \\ ${ }^{2}$ Central Department of Botany \\ Tribhuvan University \\ Kirtipur, Kathmandu \\ e-mail:nirmalaktm@gmail.com
}

\begin{abstract}
Wild vegetables were collected from forests, home gardens, road sides, fallow lands and farmers' fields of Makawanpur district. Information regarding local names, seasonal availability, mode of consumption and priority for utilization were gathered by interviews with key informants, traders' interviews and market survey of study sites. Some of nutritive values including relative importance of wild vegetables were recorded from literature. A total of 68 wild plant species belonging to 58 genera and 40 families were identified as wild vegetables. Of these, 53 species were herbs, 5 climbers, 4 species shrubs, 4 species trees, and 2 species aquatic runners. The wild vegetables were harvested mainly from March to July by women for household consumption and were also sold in the market. Amaranthus lividus, Bambusa tulda, Bauhinia purpurea, Chenopodium album, Dendrocalamus hamiltonii, Diplazium esculentum, Dryopteris cochleata, Ficus lacor, Ipomoea aquatica, Macropanax dispermus, Phytolacca acinosa, Rorripa nasturtium-aquaticum, Tectaria coduanata, were frequently used as wild vegetables. About 16 wild vegetables were sold in the market. Thus, wild vegetables not only contributed to subsistence and nutritional security of the local people, but also a source of income generation. Despite their importance, these plants have been threatened. The utilization and cultivation of these vegetables should be promoted to maintain the dietary needs of the household in Nepal. This paper attempts to highlight the use and priority of wild vegetables mainly leafy and tender shoot vegetables of Makawanpur district.
\end{abstract}

Key words: conservation, diversity, ethnobotany, neglected vegetables

\section{Introduction}

Wild plants have been used by human beings for medicinal and food purposes since time immemorial. In many parts of the world, use of wild plants not negligible (Pieroni et al. 2007). It plays a very important role in the livelihoods of rural communities as an integral part of the subsistence strategy of people in many developing countries (Zemede \& Mesfin 2001). Wild vegetables are important sources of vitamins and minerals (Odav et al. 2007). Sundriyal and Sundriyal (2003) documented the diversity and traditional values of Himalayan wild edible plants. The nutritional value of traditional wild vegetables is high (Sundriyal \&
Sundriyal 2004, Orech et al. 2007). Numerous publications provide a valuable knowledge of edible wild plants in various locations of Nepal (Anonymous 1982, Manandhar 1995, 1997, Siwakoti et. al. 1997; Shrestha \& Dhillion 2006, Bhattarai et al. 2009). However, diet surveys tend to ignore the wild plants in comparison to cultivated ones (Etkin 1994). Increased use of traditional vegetables can contribute to enhance people's health and standard of living as well as the economic and social status. Nepal houses about 1500 species as medicinal plants and about 200 species as vegetables (Manandhar 2002). Gathering of wild vegetables for both self-consumption and selling in markets are still very common practice in 
Nepal, particularly in rural areas. During food scarcity periods, a large number of people from urban and rural communities heavily depend on wild vegetables (Anonymous 1982). However, many traditional wild vegetables are replaced by the introduction of exotic vegetables and improved varieties. Further, habitat degradation and poor marketing opportunities for traditional vegetables are responsible for losing their value (Joshi et al. 2007). The wild vegetables are marginalized in current agricultural practice as well as poor utilization due to lack of awareness (Maikhuri et al. 2004). There is an urgent need for conservation of wild plants, which can be useful in case of genetic erosion or for crop improvement (Kala 2007). Most of the wild vegetables grown naturally are resistant to several biotic and abiotic stresses, they required fewer inputs, and are comparatively nutritionally superior than cultivated crops (Bhardwaj et al. 2007). Despite these advantages, most traditional wild edible plants are generally uncultivated and underutilized (Grevetti \& Ogle 2000). This study was conducted with the objectives of identifying various wild vegetables, document their uses, seasonal availability, relative importance, priorities of consumption and nutritive values of some selected species.

\section{Methodology}

\section{Study area}

Makawanpur district is situated in Inner Tarai lowland and mid-Hills of Narayani zone of the Central Development Region, Nepal (Fig. 1). The district extends over an area of 2426 sq. $\mathrm{km}$ and is located between the latitudes $27^{\circ} 10^{\prime}$ to $27^{\circ} 40^{\prime} \mathrm{N}$ and $84^{\circ} 41^{\prime}$ to $85^{\circ} 31^{\prime} \mathrm{E}$ longitudes. It ranges $166 \mathrm{~m}$ at Inner Tarai lowland (Raigaon, Hattidhunga) to $2300 \mathrm{~m}$ at

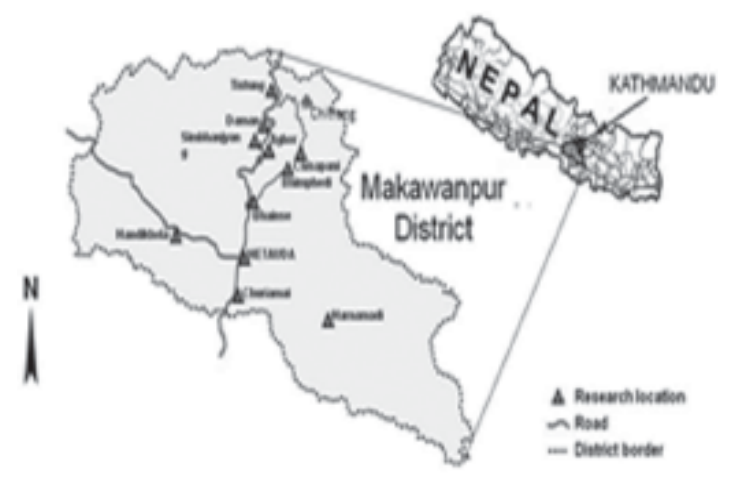

Fig. 1. Map of study sites
Mahabharat peak (mid-Hills) Simbhanjyang. It is one of the unique districts of Nepal with geographical wonders.

Makawanpur district was selected for this study due to its wide altitudinal range, rich plant diversity and diverse ethnic groups with unique traditional knowledge. The main ethnic groups in this district are Tamang (49\%), Brahmin (15\%), Chhetri (11\%), Newar (7\%), Gurung (5\%), Chepang (4\%) and Bankaria (0.02\%) (DDC 2003). The Tamang, Bankaria and Chepang are mostly living close to forests and depend a lot on the natural resources, whereas the Newar and Chhetri are traditionally farmers and living in urban and sub-urban settings. Total forest area coverage in Makawanpur district is 59\% followed by crop land 25\%, rivers and lakes 7\%, and pasture and barren land 9\% (DFO 2002). Tree vegetation is dominated by Shorea robusta, Terminalia tomentosa, Lagerstroemia parviflora, Pinus roxburghii, Quercus semecarpifolia, Myrica esculenta, etc. Shrubs include Viburnum erubescens, Rubus ellipticus, Pyracantha crenulata, Woodfordia fruticosa, etc. Detail information on altitudes, settings and ethnic groups of the study sites are given in Table 1.

\section{Data collection}

The present study was conducted in 12 sites of the district during the years 2009 to 2011 (Fig. 1, Table 1). The sites were selected in three agro-climatic zones (altitude range 400-2300 msl). Attention was given to collect the information only for leafy and tender shoot of wild vegetables.

Table 1. Altitude, ethnic groups in the selected 12 study sites of Makawanpur district

\begin{tabular}{l|l|l|l}
\hline Study site & Altitude(m) & Settings & Main ethnic groups \\
\hline Hetauda & 500 & Urban & Newar/Chhetri \\
Handikhola & $400-630$ & Rural & Bankaria \\
Hamamadi & 400 & Rural & Tamang/Chhetri \\
Churiamai & 630 & Rural & Tamang \\
Daman & 2100 & Rural & Tamang \\
Aghor & $2000-2130$ & Rural & Tamang \\
Simbhanjyang & 2300 & Rural & Tamang \\
Chisapani & 1800 & Rural & Tamang \\
Tistung & 1800 & Suburban & Newar \\
Chitlang & 1800 & Rural & Newar \\
Bhainse & 1100 & Rural & Tamang \\
Bhimphedi & 1000 & Suburban & Newar \\
\hline
\end{tabular}

Source: Field survey, 2009 
The ethnobotanical methods were applied to investigate how local people used vegetables from forests, home gardens, farmers' field, fallow land and road sides. Data were gathered by using semistructured questionnaires, informal talks, including field observation and survey of plants, in forests, crop fields and fallow lands. Market surveys and discussion with sellers were also conducted. Identification of the collected specimens was made with the help of relevant references (Hara \& Williams 1979, Hara et al. 1982, Grierson \& Long 1983-2001, Notlite 1994, 2000, Siwakoti \& Varma 1999, Press et al. 2000).

Interviews were conducted with 34 key informants who were randomly selected from four different ethnic groups such as Tamang, Newar, Chhetri and Bankaria. A list of these knowledgeable key informants was compiled with the help of respective village heads. Among them, 13 were females and 21 were males. They were asked: (1) which leafy vegetables did they use for food, (2) where and when did they harvest them, and (3) how much quantity did they consume daily/ week/month, etc.

Relative importance was ranked using the number of times the species was cited as being used by the informants (Belem et al. 2009). A survey of local villages and road side markets in the same area was done to confirm the respondent's statements on marketing potential of the mentioned species. Prioritization of the wild vegetables were prepared using a set of criteria such as taste, sale, ethnic use, and eaten by both children and adults (Joshi et al. 2011).

\section{Results and Discussion}

\section{Diversity of wild vegetables}

A total of 68 wild plant species belonging to 56 genera and 40 families was identified as leafy vegetables (Table 2). Of them, 53 (78\%) species were herbs, 5 (7\%) climbers, 4 (6\%) shrubs, 4 (6\%) trees and 2 (3\%) species aquatic runners. About $80 \%$ of the species were collected from natural or semi-natural areas, particularly forest, road side and fallow land. Wild vegetables such as Aconogonum molle, Bauhinia purpurea, Ficus lacor, Phytolacca acinosa, Bambusa tulda, Dendrocalamus hamiltonii were domesticated in home gardens by few local people. The Amaranthus lividus, A. viridis and Chenopodium album were cultivated as well as available in the wild. These species were mainly collected from the wild elsewhere, however, in the study area they were also cultivated for marketing purpose. Tragopogon gracilis and Talinum cuneifolium are the new additional wild vegetables of Nepal. A total of 23 (34\%) leafy vegetable species were collected from fallow lands followed by 9 (13\%) species from road side, 3 species from farmers' field and 2 species occurred on both road sides and farmers' fields. Similarly, 24 (35\%) species were gathered from the forests (Table 2).

Table 2. Wild vegetables used by local communities of Makawanpur district (Note: HG=homegarden; Ne=Newar, Che=Chhetri, Ta=Tamang, $\mathrm{Ba}=$ Bankaria)

\begin{tabular}{|c|c|c|c|c|c|c|c|c|c|c|c|}
\hline No. & Scientific name & Life form & Family & Local name & $\mathrm{NP}(\mathrm{RI})$ & $\begin{array}{l}\text { Collection } \\
\text { sites }\end{array}$ & $\begin{array}{l}\text { Ethnic group } \\
\text { use }\end{array}$ & $\begin{array}{l}\text { Seasonal } \\
\text { availability }\end{array}$ & Abundance & $\begin{array}{l}\text { Market } \\
\text { available }\end{array}$ & $\begin{array}{l}\text { Voucher } \\
\text { number }\end{array}$ \\
\hline \multirow[t]{2}{*}{1} & Aconogonummolle & & & & & & & & & & \\
\hline & (D. Don)H. Hara & Herb & Polygonaceae & Thotne & 16 & HG/Forest & $\mathrm{Ne}, \mathrm{Che}, \mathrm{Ta}, \mathrm{Ba}$ & May-July & Rare & Yes & $0932575 \mathrm{NJ}$ \\
\hline 2 & Allium wallichii Kunth & Herb & Liliaceae & Banlasun & 19 & Forest & $\mathrm{Ta}, \mathrm{Ba}, \mathrm{Ne}$ & Aug-Oct & Rare & No & $09823258 \mathrm{NJ}$ \\
\hline 3 & Alternanthera sessilis (L.)DC. & Herb & Amaranthaceae & Bhringisag & 5 & Roadside & $\mathrm{Ba}, \mathrm{Ta}$ & May-July & Common & No & 0931159NJ \\
\hline \multirow[t]{2}{*}{4} & Amaranthus lividus L. & Herb & Amaranthaceae & Lattesag & 26 & Roadside/ & & & & & \\
\hline & & & & & & Farmer field & $\mathrm{Ne}, \mathrm{Ta}, \mathrm{Che}, \mathrm{Ba}$ & July-Aug. & Common & Yes & 09613163NJ \\
\hline 5 & Amaranthus spinosus L. & Herb & Amaranthaceae & Kandelatte & 8 & Roadside & $\mathrm{Ba}, \mathrm{Ta}$ & July-Aug. & Common & No & $011315718 \mathrm{NJ}$ \\
\hline 6 & Amaranthus viridis L. & Herb & Amaranthaceae & Lattesag & 20 & Roadside & $\mathrm{Ne}, \mathrm{Ta}, \mathrm{Ch}, \mathrm{Ba}$ & July-Aug. & Common & Yes & 010108532NJ \\
\hline 7 & Anagallis arvensis L. & Herb & Primulaceae & Armale & 5 & Fallow land & $\mathrm{Ta}, \mathrm{Ba}$ & Aug.-Sept. & Rare & No & 092952NJ \\
\hline \multirow[t]{2}{*}{8} & Arisaema tortuosum (Wall.) & & & & & & & & & & \\
\hline & Schott. & Herb & Araceae & Banko & 5 & Forest & $\mathrm{Ta}, \mathrm{Ba}$ & Jully-Aug. & Occasional & No & $09613158 \mathrm{NJ}$ \\
\hline 9 & $\begin{array}{l}\text { Asparagus filicinus Buch.-Ham. } \\
\text { exD. Don }\end{array}$ & Herb & Asparagaceae & Bankurilo & 14 & Forest & $\mathrm{Ta}, \mathrm{Ba}$ & Mar-May & Rare & No & $01124626 \mathrm{NJ}$ \\
\hline \multirow[t]{2}{*}{10} & Asparagusracemosusvar. & & & & & & & & & & \\
\hline & subacerosusBaker & Herb & Asparagaceae & Kurilo & 18 & Forest & $\mathrm{Ta}, \mathrm{Che}, \mathrm{Ba}, \mathrm{Ne}$ & Mar-May & Rare & No & $01010853 \mathrm{NJ}$ \\
\hline 11 & Asparagus racemosusWilld. & Herb & Asparagaceae & Kurilo & 18 & Forest & $\mathrm{Ta}, \mathrm{Che}, \mathrm{Ba}, \mathrm{Ne}$ & Mar-May & Rare & No & $09924278 \mathrm{NJ}$ \\
\hline 12 & Bambusatulda Nees & Shrub & Poaceae & Tusa & 30 & HG/Forest & $\mathrm{Ne}, \mathrm{Che}, \mathrm{Ta}, \mathrm{Ba}$ & Mar-May & Rare & Yes & 0951135NJ \\
\hline 13 & BaselaalbaL. & Climber & Basellaceae & Poisag & 9 & Roadside & $\mathrm{Ba}$ & June-July & Rare & No & $0114800 \mathrm{NJ}$ \\
\hline 14 & Bauhiniapurpurea L. & Tree & Leguminosae & Tanki & 25 & HG/Forest & $\mathrm{Ta}, \mathrm{Ba}$ & Mar-May & Rare & No & 01010444NJ \\
\hline 15 & Bidens pilosa L. & Herb & Compositae & Kuro & & Roadside & $\mathrm{Ba}$ & June-July & Common & No & $011317731 \mathrm{NJ}$ \\
\hline 16 & Blumealacera (Burm.f.) & & & & & & & & & & \\
\hline \multirow{2}{*}{17} & DC. & Herb & Compositae & Kurkure & 10 & Roadside & $\mathrm{Ba}, \mathrm{Ne}$ & May-June & Occasional & No & $0931160 \mathrm{NJ}$ \\
\hline & D. Don & Herb & Urticaceae & Kamle & 14 & Forest & $\mathrm{Ta}, \mathrm{Ba}$ & Jun-Aug & Occasional & No & 09823244NJ \\
\hline
\end{tabular}


Nepal Journal of Science and Technology Vol. 13, No. 1 (2012) 59-66

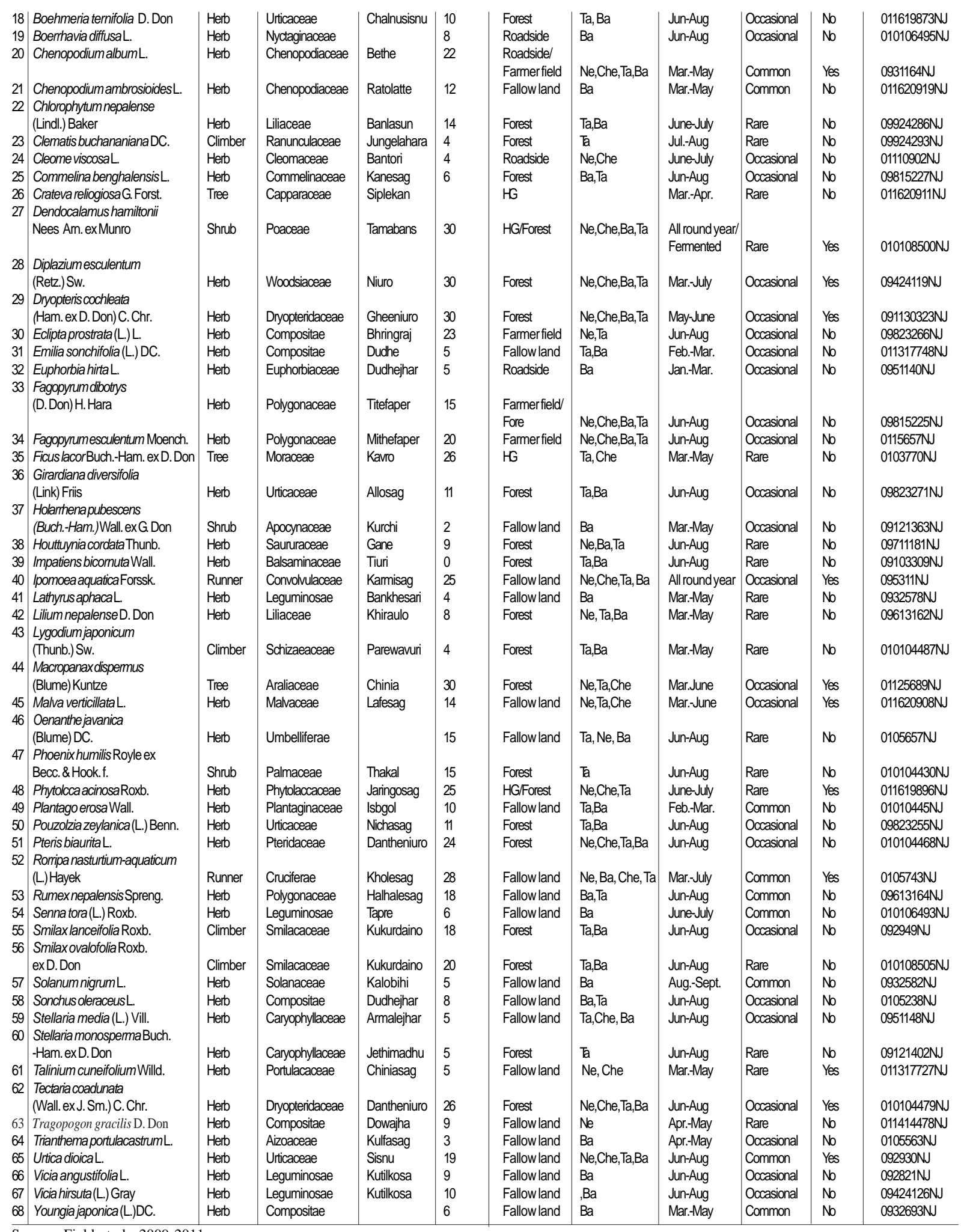

Source: Field study 2009-2011

NP: Number of persons who cited the species. Total number of informants is 34; RI: Relative importance 
According to local peoples' perception, wild vegetables with high relative importance (RI) in this area were Amaranthus lividus, B. tulda, B. purpurea, C. album, D. hamiltonii, Dryopteris cochleata, Eclipta prostrata, Ficus lacor, Ipomoea aquatica, Macropanax dispermus, Phytolacca acinosa, Rorripa nasturtium-aquaticum, Tectaria coadunata, etc. (Table 2).

\section{Consumption and nutritive value of wild vegetables}

Rural women were the major players in utilizing wild traditional food plants including vegetables. They held and maintained a good knowledge on gathering locations and seasons, preservation, consumption and processing of wild vegetables. It was found that Tamang and Bankaria communities were the major consumers of wild vegetables as they lived nearby the forest. The Newar and Chhetri mainly lived in urban and sub-urban areas and were attracted to more improved varieties and exotic vegetables than wild vegetables.

The estimated quantity of fresh vegetables consumed by each informant's house per day during the period of survey was nearly $500 \mathrm{~g}$. The average number of persons in each household was 10 , hence each person consumed $50 \mathrm{~g}$ of wild vegetables per day. Based on the interviews with key informants during field visits, the following 7 species were top ranked with regard to taste and consumption frequency by both children and adults: B. tulda, C. album, D. hamiltonii, Diplazium esculentum, Dryopteris cochleata, Ipomoea aquatica, Tectaria coduanata. The second ranked preferred species were $A$. viridis, Macropanax dispermus, Pteris biaurita, Urtica dioica (Table 3). These wild vegetables did not require any special

Table 3. Potential priority wild vegetables of Makawanpur district with their ranking after calculating the priority index

\begin{tabular}{|c|c|c|c|c|c|c|}
\hline Species & $\begin{array}{l}\text { Priority } \\
\text { for taste } \\
\text { (3=high) }\end{array}$ & $\begin{array}{l}\text { Priority } \\
\text { for sale } \\
\text { (3=high) }\end{array}$ & $\begin{array}{c}\text { Ethnic } \\
\text { groups use } \\
\text { (no.) }\end{array}$ & $\begin{array}{l}\text { Eaten by children } \\
\text { and adults ( } 1=\text { Yes) }\end{array}$ & $\begin{array}{l}\text { Priority } \\
\text { index }\end{array}$ & $\begin{array}{c}\text { Rank for } \\
\text { consumption }\end{array}$ \\
\hline Aconogonum molle & 2 & 2 & 4 & 0 & 8 & 4 \\
\hline Amaranthus lividus & 2 & 3 & 4 & 0 & 9 & 3 \\
\hline Amaranthus spinosus & 1 & 1 & 2 & 0 & 4 & 8 \\
\hline Amaranthus viridis & 3 & 3 & 4 & 0 & 10 & 2 \\
\hline Bambusa tulda & 3 & 3 & 4 & 1 & 11 & 1 \\
\hline Asparagus filicinus & 3 & 1 & 2 & 1 & 7 & 5 \\
\hline Asparagus racemosus & 3 & 1 & 4 & 1 & 9 & 3 \\
\hline Asparagus racemosus & & & & & & \\
\hline var. subacerosus & 3 & 1 & 4 & 1 & 9 & 3 \\
\hline Chenopodium album & 3 & 3 & 4 & 1 & 11 & 1 \\
\hline Chlorophytum nepalense & 3 & 1 & 2 & 1 & 7 & 5 \\
\hline Dendrocalamus & & & & & & \\
\hline hamiltonii & 3 & 3 & 4 & 1 & 11 & 1 \\
\hline Diplazium esculentum & 3 & 3 & 4 & 1 & 11 & 1 \\
\hline Dryopteris cochleata & 3 & 3 & 4 & 1 & 11 & 1 \\
\hline Eclipta prostrata & 3 & 2 & 2 & 0 & 7 & 5 \\
\hline Girardiana diversifolia & 2 & 1 & 2 & 0 & 5 & 7 \\
\hline Ipomoea aquatica & 3 & 3 & 4 & 1 & 11 & 1 \\
\hline Macropanax dispermus & 3 & 3 & 3 & 1 & 10 & 2 \\
\hline Phoenix humilis & 3 & 1 & 1 & 1 & 6 & 6 \\
\hline Phytolacca acinosa & 3 & 2 & 3 & 0 & 8 & 4 \\
\hline Pteris biaurita & 3 & 2 & 4 & 1 & 10 & 2 \\
\hline Smilax ovalifolia & 3 & 1 & 2 & 0 & 7 & 5 \\
\hline Talinum cuneifolium & 3 & 2 & 2 & 0 & 7 & 5 \\
\hline Tectaria coadunata & 3 & 3 & 4 & 1 & 11 & 1 \\
\hline Urtica dioica & 3 & 3 & 4 & 0 & 10 & 2 \\
\hline
\end{tabular}

Source: Field study 2009-2011 
processing for cooking or consumption, except the removal of stings and some other microstructures of nettles of some species. All wild vegetables were boiled and cooked with cooking oil, salt and spices. However, some of wild vegetables were boiled and prepared by mixing with fried seed powder of Glycine max, Sesamum indicum or Perilla frutescens (Table 4). Some species like Phytolacca acinosa leaves required some special treatment in order to reduce the bitterness, such as boiled and washed several times before the final preparation of vegetable. Wild vegetables were nutritious as they contained high protein and other nutrients which helped in the food security of rural people. Nutrient values of some priority wild vegetables are given in (Table 5). This table is based on the work of Sundriyal and Sundriyal (2004).

Table 4. Traditional knowledge on mode of consumption of prioritized wild vegetables

\begin{tabular}{|c|c|c|c|}
\hline Species name & Occurrence & Part used & Mode of consumption \\
\hline Bambusa tulda & $\begin{array}{l}\text { Grows in forest edge, also } \\
\text { cultivated in home garden. }\end{array}$ & Tender shoots & $\begin{array}{l}\text { Outer covering is removed. Soft inner } \\
\text { shoots are smashed and fried with } \\
\text { cooking oil or cooked with potato. }\end{array}$ \\
\hline $\begin{array}{l}\text { Chenopodium } \\
\text { album }\end{array}$ & $\begin{array}{l}\text { Occurs in fallow land. Women } \\
\text { cultivated in potato and } \\
\text { wheat crops. }\end{array}$ & Tender shoots & $\begin{array}{l}\text { Tender shoots are fried with egg. } \\
\text { Tender shoots are also mixed with } \\
\text { Glycine max, Perilla frutescens, } \\
\text { Sesamum indicum fried flour and spices. }\end{array}$ \\
\hline $\begin{array}{l}\text { Dendrocalamus } \\
\text { hamiltonii }\end{array}$ & $\begin{array}{l}\text { Commonly occurs in forest area } \\
\text { and roadside. This plant is } \\
\text { collected from wild, also found } \\
\text { domesticated in home garden. }\end{array}$ & Tender shoot & $\begin{array}{l}\text { Cooked with potato. Also cut into } \\
\text { small pieces and covered with Banana } \\
\text { leaves to make fermented shoot, which } \\
\text { can be preserved for longer period. }\end{array}$ \\
\hline Diplazium esculentum & Frequently occurs in moist forest. & Tender fronds & Fried with cooking oil \\
\hline Dryopteris cochleata & Frequently occurs in moist forest. & Tender fronds & Fried with cooking oil \\
\hline Ipomoea aquatica & $\begin{array}{l}\text { Grows in slow running water and } \\
\text { pond. }\end{array}$ & $\begin{array}{l}\text { Tender shoot } \\
\text { and leaves }\end{array}$ & Fried with cooking oil \\
\hline
\end{tabular}

Source: Field study 2009-2011

\section{Marketing and income generation}

A total of 16 wild vegetable species were found to be sold in the urban markets (Table 2). In rural markets only few vegetables were sold. The common marketable wild vegetables were $D$. esculentum, A. lividus, $A$. viridis, B. tulda, D. hamiltonii, D. cochleata, Fagopyrum esculentum, Ipomoea aquatica, Macropanax dispermus, Malva verticillata, Rorripa nasturtium-aquaticum, Talinum cuneifolium and Urtica dioica. Some species such as F. esculentum, A. viridis, C. album were cultivated mainly for selling in the markets. The market price of leafy vegetables ranged from 20-40 rupees per one bundle (about 400$500 \mathrm{~g}$ ). It is found that one vegetable seller earned up to Rs100 per day. It means marketing of vegetables could contribute to income generation and poverty reduction in the study areas.

\section{Seasonal availability of the wild vegetable}

Availability of wild vegetables varied season to season of the year. Informants reported that the highest number of species i.e 37 species could be harvested in the months of May to August, whereas only few species are harvested in the month of January to April (Table 2). Some species such as A. lividus, A. viridis, $U$. dioica, $R$. nasturtium-aquaticum, were consumed during the vegetable shortage period.
Abundance of wild vegetables
Out of the 68 wild vegetable species, 26 were threatened in their abundance in the natural habitats, mainly the forest areas (Table 2). A variety of reasons were mentioned by local communities for species reduction in their natural habitat. The main reasons or threat were the unsustainable harvesting methods, land erosion, increase of agricultural land area, poor marketing opportunities, etc. It was also mentioned that there was an increasing practice of cultivating exotic and improved varieties of vegetables instead of indigenous wild ones. 
Table 5. Nutritive value of some wild vegetables

\begin{tabular}{|c|c|c|c|c|c|c|c|}
\hline Botanical name & Protein (\%) & $\begin{array}{l}\text { Vitamin C } \\
\mathrm{mg} / 100 \mathrm{~g}\end{array}$ & K (\%) & P (\%) & Сa (\%) & $\mathrm{Na}(\%)$ & $\mathrm{Fe}(\mathrm{mg} / 100 \mathrm{~g})$ \\
\hline $\begin{array}{l}\text { Bambusa tulda } \\
\text { Chenopodium album } \\
\text { Dendrocalamus hamiltonii } \\
\text { Euphorbia hirta } \\
\text { Fagopyrum esculentum } \\
\text { Rorripa nasturtium- aquaticum } \\
\text { Oenanthe javanica } \\
\text { Phytolacca acinosa } \\
\text { Plantago major } \\
\text { Sonchus oleracea } \\
\text { Urtica dioica }\end{array}$ & $\begin{array}{l}3.9 \\
4.63 \\
3.9 \\
4.65 \\
10.3 \\
2.09 \\
17.13 \\
27.25 \\
\\
18.7 \\
30.4\end{array}$ & $\begin{array}{l}564.1 \\
17.5\end{array}$ & $\begin{array}{l}0.057 \\
0.5 \\
3.61 \\
4.96 \\
5.6 \\
0.03\end{array}$ & $\begin{array}{l}0.041 \\
0.065 \\
0.36 \\
0.68 \\
0.22 \\
0.21 \\
0.36\end{array}$ & $\begin{array}{l}0.033 \\
1.12 \\
0.12 \\
1\end{array}$ & 0.039 & $\begin{array}{l}64.9 \\
42.6 \\
13 \\
17 \\
23\end{array}$ \\
\hline
\end{tabular}

Source: Sundriyal and Sundriyal (2004)

Note: $\mathrm{K}=$ Pottasium, $\mathrm{P}=$ Phosphorus, $\mathrm{Ca}=$ Calcium, $\mathrm{Na}=$ Sodium, $\mathrm{Fe}=$ Iron

The informants were asked to classify the abundance of the 68 wild vegetable species in three classes, from common, occasional and rare. They classified 14 species as common, 28 occasional and 26 species rare. The species such as D. esculentum, Malva verticillata, I. aquatica, B. tulda, Dryopteris cochleata, Aconogonum molle, Asparagus racemosus, A. filicinus, etc., were considered to be rare because they had a high demand at local markets, hence unsustainable harvesting has been increased in their natural habitats. Indigenous wild vegetable species are also far neglected in regional and national policies and no conservation or domestication strategies to promote them. Introduction of exotic vegetable species, improved varieties, and poor marketing value including urbanization process have contributed to decrease the abundance of wild vegetables.

Traditional knowledge on the use of wild plants is still practiced by the rural people of Makawanpur district those lived close to forests. Rural communities in these areas are more knowledgeable about wild vegetables. There may be more than 68 species of wild vegetables species in this study, therefore, detailed research in the future is still needed. Women are important partners as they play the major role in the collection, preparation and marketing of wild vegetables. Wild vegetable are tasty and rich in proteins, amino acids, and vitamins. The indigenous people have also knowledge about toxicity of plants that is usually increased in mature state. Such knowledge are lacking in people of urban area. Wild vegetables are mainly sold at road side local markets. There is a great potential for domesticating the wild vegetable.

\section{Acknowledgements}

The authors are thankful to Prof. Dr. Pramod K. Jha, Head, Prof. Dr. Krishna K. Shrestha, Tribhuvan University, Central Department of Botany, Kirtipur, for providing facilities for this work. We are also thankful to Prof. Dr. Ram P. Chaudhary for valuable comments and suggestions. We also thank the Department of Plant Resources, Thapathali, Ministry of Forests and Soil Conservation, for giving permission to conduct this study. Nepal Academy of Science and Technology is thanked for providing financial support. Thanks are also due to local communcities of the study area for providing us valuable traditional knowledge and help for plant collections.

\section{References}

Anonymous. 1982. 1982. Wild edible plants of Nepal. Bulletin, Department of Medicinal Plants, No. 9, Thapathali, Kathmandu, 285 pp.

Bhattarai, S., R.P. Chaudhary and R.S.L. Taylor. 2009. Wild edible plants used by the people of Manang district, Central Nepal. Ecology of Food and Nutrition. 48: 1-20.

Belem, B., B.C. Sane and E.L.Y. Ouattara. 2009. Wild leafy vegetables in the community of Seguenega, Northen Burkina Faso and Their contribution to food security and income generation. Acta Horticulturae, 806. 121-127. 
Nepal Journal of Science and Technology Vol. 13, No. 1 (2012) 59-66

Bhardwaj, R., A.K. Rai, Sureja, A.K. and D. Singh. 2007. Nutritive value of indigenous vegetables of Arunchal Pradesh. In: Proceeding of $2^{\text {nd }}$ Indian Horticulture Congress-Opportunities and Linkages for Horticulture Research and Development, ICAR-Complex for NE Region. Barapani, Meghalaya 18-21 April, 169 p.

DDC. 2003. District profile of Makawanpur, District Development Committee, Makawanpur district, Hetauda, Nepal, 98 p.

DFO. 2002. Records of traded NTFP's. District Forest Office, Makawanpur, Hetauda, Nepal, 43 p.

Etkin, N.L. 1994. The cull of the wild. In: Eating on the wild side: The pharmacologic, ecologic and social implications of using noncultigens (Ed. N.L. Etkin). Tucson/London: University of Arizona Press. Pp. 1-21.

Grierson, A. J.C. and D.G. Long. 1983-2001. Flora of Bhutan. Vol. 1, Part 1; Vol. 2. Part 3. Royal Botanic Gardens Edinburgh and Royal Government of Bhutan.

Grivetti, L.E., B.M. Ogle. 2000. Value of traditional foods in meeting macro-and micronutrient needs: The wild plant connection. Nutrition Research Reviews 13:31-46.

Hara, H. and L.H.J. Williams (Eds.). 1979. An enumeration of the flowering plants of Nepal, Vol. 2. British Museum of Natural History, London, 220 p.

Hara, H., A.O. Chater and L.H.J. Williams (Eds.). 1982. An enumeration of the flowering plants of Nepal, vol. 3. British Museum of Natural History, London. 226 pp.

Joshi, N., B.L. Maass and K. Kehlenbeck. 2007. Traditional, neglected vegetables of Nepal: Their sustainable utilization for meeting human needs. Tropentag, October 9-11, 2007, University of Goettingen, University of Kassel, Witzenhausen, Germany. www.tropentag.de/2007/ abstracts/full/322/pdf. Proceedings 2007.

Joshi, N., M. Siwakoti and K. Kehlenbeck. 2011. Developing a priority setting approach for domestication of indigenous fruit and nut species in Makawanpur district, Nepal. Book of Abstract, pp 44. Oral paper presentation at $2^{\text {nd }}$ International Symposium on Underutilized Plant Species "Crops for the FutureBeyond Food Security $27^{\text {th }}$ June- $1^{\text {st }}$ July 2011, The Royale Chulan Kuala Lumpur, Malaysia.

Kala, C.P. 2007. Prioritization of cultivated and wild edibles by local people in the Uttaranchal hills of Indian Himalaya. Indian Journal of Traditional Knowledge 6: $269-243$

Maikhuri, R.K., K.S. Rao and K.G. Saxena. 2004. Bioprospecting of wild edibles for rural development in central Himalaya. Mountain Research and Development 24: 110-113.
Manandhar, N.P. 1995. Ethnobotanical notes on unexploited wild food plants of Nepal. Ethnobotany 7(1-2): 95-101.

Manandhar, N.P. 1997. Unreported wild food plants of Nepal. Ethnobotany 9(1-2): 97-100.

Manandhar, N.P. 2002. Plants and people of Nepal. Timber Press Portland, Oregon, USA. 599 pp.

Notlite, H.J. 1994. Flora of Bhutan, Vol. 3, Part 1. Royal Botanic Garden, Edinburgh, UK and Royal Government of Bhutan, $456 \mathrm{p}$.

Notlite, H.J. 2000. Flora of Bhutan, Vol. 3, Part 2. Royal Botanic Garden, Edinburgh, UK and Royal Government of Bhutan, 883 p.

Odav, B., S. Beekrum, U.S. Akula and H. Baijnath. 2007. Preliminary assessment of nutritional value of traditional leafy vegetables in Kwazulu-Natal, South Africa. Journal of Food Composition and Analysis 20: 430-435.

Orech, F.O., J. Aagaard-Hansen and H. Friis. 2007. Ethnoecology of traditional leafy vegetables of the Luo people of Bondo district, western Kenya. International Journal of Food Science and Nutrition 58(7): 522-530.

Pieroni, A., L. Houlihan, N. Ansari, B. Hussain and S. Aslam. 2007. Medicinal perceptions of vegetables traditionally consumed by South Asian migrants living in Bradford, Northern England. Journal of Ethnopharmacology 113: 100-110.

Press, J.R., K.K. Shrestha and D.A. Sutton. 2000. Annotated checklist of the flowering plants of Nepal. The Natural History Museum, London, 430 p.

Shrestha, P.M. and S.S. Dhillion. 2006. Diversity and traditional knowledge concering wild food species in a locally managed forest in Nepal. Agroforestry Systems 66: $55-63$.

Siwakoti, M. and S.K. Varma. 1999. Plant diversity of eastern Nepal: Flora of plains of eastern Nepal. M/S Bishen Singh Mahendra Pal Singh, Dehra Dun, India, $491 \mathrm{p}$.

Siwakoti, M., S. Siwakoti and S.R. Varma. 1997. Ethnobotanical notes on wild edible plants used by the Satars of Nepal. Tribhuvan University Journal 20(1): 57-64.

Sundriyal, M. and R.C. Sundriyal. 2003. Underutilized edible plants of the Sikkim Himalaya: Need for domestication. Current Science 85: 731-736.

Sundriyal, M. and R.C. Sundriyal. 2004. Wild edible plants of the Sikkim Himalaya: Nutritive values of selected species. Economic Botany 58:286-299.

Zemede, A. and T. Mesfin. 2001. Prospects for sustainable use and development of wild food plants in Ethiopia. Economic Botany 55: 47-62. 